\title{
PENATAAN ADMINISTRASI PEMERINTAHAN DESA DI DESA KUALU NENAS KECAMATAN TAMBANG KABUPATEN KAMPAR
}

\author{
Muammar Alkadafi ${ }^{1}$, Rusdi ${ }^{2}$, Muhammad April ${ }^{3}$ \\ ${ }^{1,2,3}$ Fakultas Ekonomi Dan Ilmu Sosial Uin Suska Riau; Jl. HR. Soebrantas No. 155 KM 15, Telp. \\ 0761-562051 \\ *E-mail: alkadafi.amar@gmail.com
}

\begin{abstract}
An important problem in the implementation of village management, in order to realize good governance, is the lack of good and correct governance of village administration by village government officials. Kualu Nenas Village is one of the villages that has not yet arranged the administration of the village administration as stipulated in Permendagri Number 47 of 2016 concerning Guidelines for Village Government Administration. Service method; a. provide exposure to material about structuring village administration, $b$. Demonstrating the filling of general administration, population, finance, development books and other administrative books, c. guide village office staff in making village government administration books in accordance with guidelines, Community Service Results; kualu nenas village government apparatus can understand and know about the governance of village government administration that is good and correct in accordance with Permendagri No. 47 of 2016, village government administration in kualu nenas village which has been incomplete, disorderly and orderly, has changed for the better with the creation of village government administration books, which are continuously filled by village office staff to produce upto-date and accurate village data and information.
\end{abstract}

Keywords: Arrangement, Governance, Village Government Administration.

\begin{abstract}
Abstrak
Masalah penting dalam implementasi pengelolaan desa, dalam rangka mewujudkan tata kelola pemerintah desa yang baik (good governance), adalah minimnya penataan administrasi pemerintahan desa yang baik dan benar oleh aparatur pemerintah desa. Desa Kualu Nenas merupakan salah satu desa yang belum melakukan penataan administrasi pemerintahan desa sebagaimana yang diatur dalam Permendagri Nomor 47 Tahun 2016 Tentang Pedoman Administrasi Pemerintahan Desa. Metode pengabdian; a. memberikan paparan materi tentang penataan administrasi pemerintahan desa, $b$. Mendemonstrasikan pengisian buku administrasi umum, kependudukan, keuangan, pembangunan dan buku administrasi lainnya, c. memandu staf kantor desa dalam pembuatan buku administrasi pemerintahan desa sesuai dengan pedoman, Hasil Pengabdian; aparatur pemerintah desa kualu nenas dapat memahami dan mengetahui tentang tata kelola administrasi pemerintahan desa yang baik dan benar sesuai dengan Permendagri No 47 tahun 2016, administrasi pemerintahan desa di desa kualu nenas yang selama ini tidak lengkap, tidak tertata dan teratur, berubah menjadi lebih baik dengan terciptanya buku-buku administrasi pemerintahan desa, yang secara terus menerus diisi oleh staf kantor desa untuk mengahasilkan data dan informasi desa yang up-todate dan akurat.
\end{abstract}

Kata Kunci : Penataaan, Tata Kelola, Administrasi Pemerintahan Desa.

\section{PENDAHULUAN}

Pemerintahan Desa merupakan subsistem dari pemerintahan nasional yang menjadi pondasi pemerintahan pusat dalam menerima data dan informasi untuk penentuan berbagai kebijakan pemerintahan secara nasional. keberhasilan penataan Administrasi Pemerintahan Desa merupakan cerminan keberhasilan penyelenggaraan pemerintahan desa, yang berdaya guna dan berhasil guna. Semakin baiknya penataan administrasi desa maka good governance desa atau tata kelola pemerintahan desa semakin baik. Semakin baik penyelenggaraan administrasi pemerintahan desa 
semakin mendekati upaya mewujudkan desa maju dan mandiri sebagaimana diharapkan oleh Undang-Undang Nomor 6 Tahun 2014 Tentang Desa dan sekaligus mendukung pelaksanaan otonomi daerah.

Pembangunan desa menjadi salah satu agenda penting strategis Nasional yang termuat dalam Nawa Cita ketiga pemerintahan Jokowi-JK, yang menyebutkan "membangunan Indonesia dari pinggiran dengan memperkuat daerah-daerah dan desa dalam kerangka Negara kesatuan".di dalam Rencana Pembangunan Jangka Menengah Nasional (RPJMN) 2015-2019 pemerintah menargetkan untuk mengurangi jumlah Desa Tertinggal sampai 5000 Desa, dan meningkatkan jumlah Desa Mandiri sedikitnya 2000 Desa pada tahun 2019. (Hanibal Hamidi, et al. 2015: 1). Secara kuantitas pertumbuhan jumlah pemerintah desa terus mengalami peningkatan, Data dari Kemendagri Republik Indonesia tahun 2015 menyebutkan jumlah desa di Indonesia berjumlah 74.053 Desa. Dari jumlah tersebut dapat dilihat dari status dan kriteria desa di Indonesia.

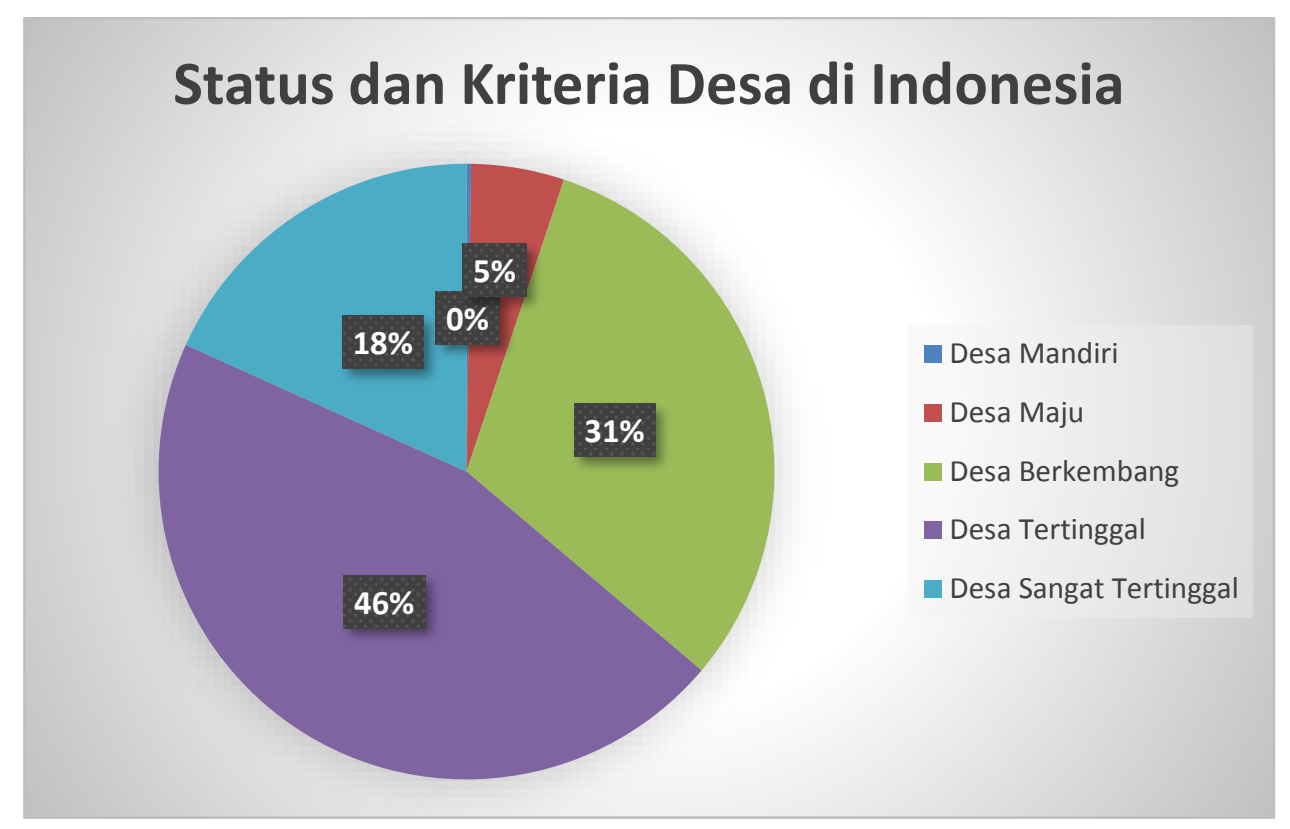

Gambar 1 Status dan Kriteria Desa di Indonesia

Sumber: Kementerian Desa, PDT, dan Transmigrasi Tahun 2014

Desa mandiri menjadi visi-misi Undang-Undang Desa dan menjadi tolak ukur pencapaian otonomi desa. Desa Mandiri atau bisa disebut sebagai desa sembada adalah desa maju yang memiliki kemampuan melaksanakan pembangunan desa untuk peningkatan kualitas hidup dan kehidupan sebesar-besarnya kesejahteraan masyarakat desa dengan ketahanan sosial, ketahanan ekonomi, ketahanan ekologi secara berkelanjutan. Desa Maju , atau disebut desa seabgai desa pra sembada adalah desa yang memiliki potensi sumber daya sosial, ekonomi, dan ekologi, serta kemampuan mengelolanya untuk peningkatan kesejahteraan masyarakat desa, kualitas hidup manusia, dan menanggulangi kemiskinan. Desa Berkembang, atau bisa disebut sebagai desa Madya adalah desa potensial menjadi desa maju, yang memiliki potensi sumber daya sosial, ekonomi dan ekologi tetapi belum mengelolalanya secara optimal untuk peningkatan kesejahteraan masyarakat desa, kualitas hidup manusia dan menganggulangi kemiskinan. Desa Tertinggal, atau disebut sebagai desa Pra-Madya adalah desa yang memiliki potensi sumber daya sosial, ekonomi dan ekologi tetapi belum, atau kurang mengelolanya dalam upaya peningkatan kesejahteraan masyarakat desa, kualitas hidup manusia serta mengalami kemiskinan dalam berbagai bentuknya. Desa Sangat Tertinggal, atau disebut sebagai desa Pratama adalah desa yang mengalami kerentanan karena masalah bencana alam, goncangan ekonomi, dan konflik sosial, sehingga tidak berkemampuan mengelola potensi sumber daya sosial, ekonomi dan ekologi, serta mengalami kemiskinan dalam berbagai bentuknya. (Permendes PDT, dan Transmigrasi No 2 Tahun 2016). 
Salah satu langkah untuk membangun desa mandiri ialah implementasi system perencanaan, penganggaran dan pelaksanan anggaran desa yang partisipatif, tertib, efektif, efisien dan disertai monitoring yang baik. (Kurniawan, 2015:48). Langkah tersebut, hanya dapat direalisasikan dengan baik, bila terciptanya Administrasi Pemerintahan Desa yang tertib sebagai basis data dan informasi.

Tabel 1 Status dan Kriteria Desa di Provinsi Riau

\begin{tabular}{llcc}
\hline No. & Indeks Desa Membangun & Jumlah Desa & Persentase (\%) \\
\hline 1 & Desa Mandiri & 0 & 0,0 \\
\hline 2 & Desa Maju & 9 & 0,56 \\
\hline 3 & Desa Berkembang & 278 & 31,04 \\
\hline 4 & Desa Tertinggal & 888 & 55,4 \\
\hline 5 & Desa Sangat Tertinggal & 428 & 26,7 \\
\hline
\end{tabular}

Sumber : Data Olahan, 2018

Desa Kualu Nenas merupakan salah satu desa yang berada diwilayah dekat dengan perbatasan Kota Pekanbaru (Ibukota Provinsi) dengan Kabupaten Kampar. Kabupaten Kampar memiliki 242 desa, berikut status desa-desa yang ada diwilayah Kabupaten Kampar.

Tabel 2 Status dan Kriteria Desa di Kabupaten Kampar

\begin{tabular}{llcc}
\hline No & Indeks Desa Membangun & Jumlah Desa & Persentase (\%) \\
\hline 1 & Desa Mandiri & 0 & 0,0 \\
\hline 2 & Desa Maju & 2 & 0,008 \\
\hline 3 & Desa Berkembang & 48 & 11,6 \\
\hline 4 & Desa Tertinggal & 140 & 33,8 \\
\hline 5 & Desa Sangat Tertinggal & 52 & 12,5 \\
\hline
\end{tabular}

Sumber : Data Olahan, 2018

Tabel 2 diatas menunjukkan bahwa belum ada desa yang berstatus desa mandiri dan baru 2 (dua) desa yang berstatus desa maju. Sebagian besar desa di Kabupaten Kampar adalah termasuk kategori desa sangat tertinggal $(12,5 \%)$ dan desa tertinggal $(33,8 \%)$.

Tabel 3 Status dan Kriteria Desa di Kecamatan Tambang Kabupaten Kampar

\begin{tabular}{|c|c|c|}
\hline No & Nama Desa & Indeks Desa Membangun \\
\hline 1 & Kuapan & Berkembang \\
\hline 2 & Aur Sati & Tertinggal \\
\hline 3 & Tambang & Tertinggal \\
\hline 4 & Padang Luas & Sangat Tertinggal \\
\hline 5 & Gobah & Tertinggal \\
\hline 6 & Terantang & Sangat Tertinggal \\
\hline 7 & Rimbo Panjang & Berkembang \\
\hline 8 & Kualu & Tertinggal \\
\hline 9 & Teluk Kenidai & Tertinggal \\
\hline 10 & Parit Baru & Sangat Tertinggal \\
\hline 11 & Kemang Indah & Tertinggal \\
\hline 12 & Sungai Pinang & Tertinggal \\
\hline 13 & Kualu Nenas & Berkembang \\
\hline 14 & Tarai Bangun & Tertinggal \\
\hline 16 & Palung Raya & Tertinggal \\
\hline 17 & Pulau Permai & Tertinggal \\
\hline
\end{tabular}

Sumber : Data Olahan, 2018

Desa Kualu berada di wilayah Kecamatan Tambang dengan status desa berkembang. Jika dibandingkan dengan 16 desa lainnya di Kecamatan Tambang, Desa Kualu sedikit lebih maju karena 
desa lainnya masih berstatus desa tertinggal dan sangat tertinggal, namun karena lokasi Desa Kualu Nenas merupakan salah satu wilayah penyangga setelah Desa Rimbo Panjang yang berbatas langsung dengan Kota Pekanbaru (Ibu Kota Provinsi Riau). Desa Kualu Nenas merupakan desa yang ditetapkan sebagai desa Berkembang. Desa Kualu Nenass memiliki potensi yang besar, karena memiliki potensi dibidang pertanian nenas sebagai produk unggulan masyarakat. Namun potensi yang besar tersebut belumlah terdata secara baik dalam data potensi atau profil desa.

Tata Kelola Pemerintah Desa yang baik (Good Governance), dimulai dengan komitmen aparatur pemerintah desa untuk menertibkan administrasi pemerintahan desa. Keberhasilan penyelenggaraan pemerintahan desa, terutama dalam pelaksanaan urusan pemerintahan dan pelaksanaan pembangunan, akan tergantung kepada aspek perencanaan yang baik. Penyusunan perencanaan desa akan bersumber kepada data dan informasi yang akurat. Salah satu poin penting dalam Peraturan Menteri Dalam Negeri Nomor 81 Tahun 2015 Tentang Evaluasi Perkembangan Desa Dan Kelurahan ialah mengenai terpenuhinya administrasi desa yang lengkap di Kantor Desa.

Untuk menciptakan keteraturan penyelenggaraan pemerintahan, desa harus memiliki Buku Administrasi Umum, Buku Administrasi Kependudukan, Buku Administrasi Keuangan, Buku Administrasi Pembangunan, dan Administrasi Lainnya sesuai kebutuhan desa yang bersangkutan sebagaimana diatur didalam Peraturan Menteri Dalam Negeri Nomor 47 Tahun 2016 Tentang Administrasi Pemerintahan Desa.

Salah satu kewenangan desa yang tertuanga dalam Undang - Undang Nomor 6 tahun 2014 tentang Desa ialah kewenangan lokal berskala desa yang memuat 4 (empat) bidang kewenangan yaitu Penyelenggaraan Pemerintahan Desa, Pelaksanaan Pembangunan, Pembinaan Kemasyarakatan, dan Pemberdayaan Masyarakat. (Silahuddin, 2015:12)

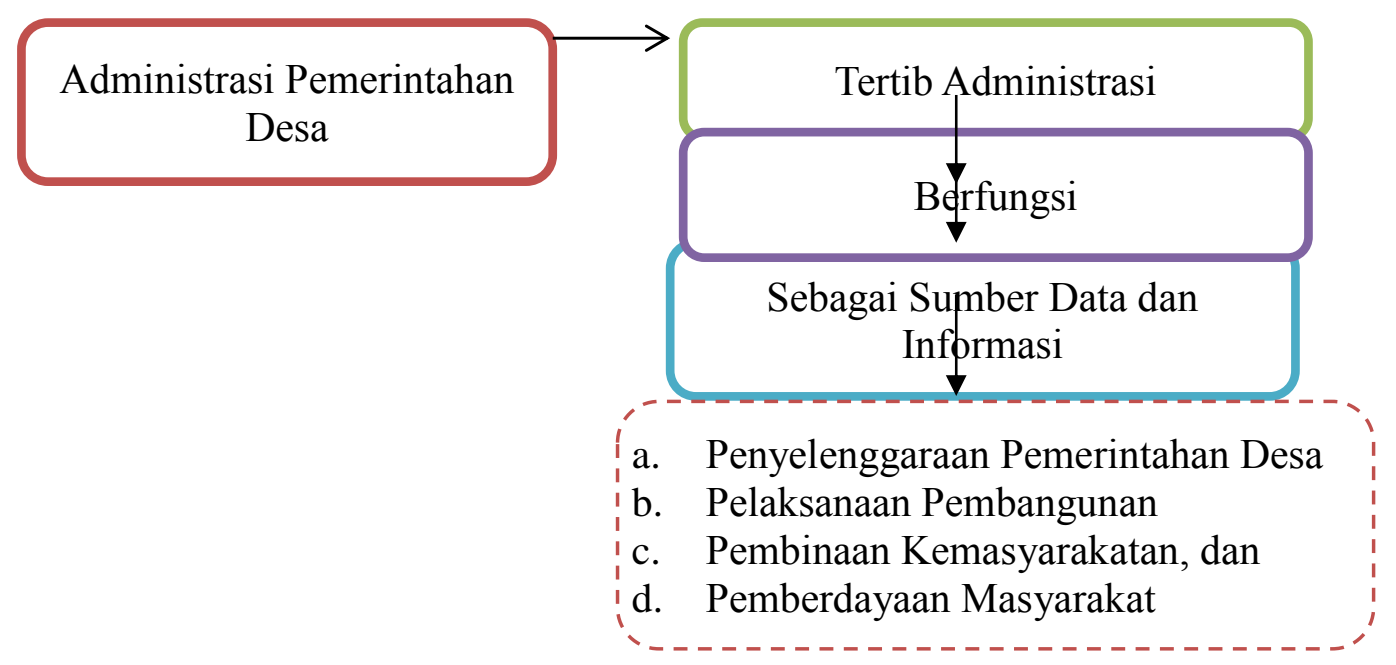

Gambar 2 Pentingnya Administrasi Pemerintahan Desa dalam Tata Kelola Desa

Desa Kualu Nenas Kabupaten Kampar, salah satu desa yang belum menata administrasi pemerintahan desa, sesuai dengan pedoman yang diatur dalam Peraturan Menteri Dalam Negeri Nomor 47 Tahun 2016 Tentang Administrasi Pemerintahan Desa. Hal tersebut dikarenakan dari keterangan aparat desa Kualu Nenas, bahwa pedomana administrasi pemerintahan desa, belum pernah dilakukan sosialisasi maupun pelatihan kepada kami sebagai aparatur desa oleh pihak manapun, baik itu para tenaga pendamping desa, pemerintah Kabupaten Kampar maupun pemerintah provinsi.

Pemberdayaan terhadap bidang penguatan kapasitas penyelenggaraan pemerintahan desa, selama ini masih minim dilakukan, kegiatan-kegiatan pemberdayaan yang dilakukan di desa melalui program Pemerintah Pusat, Provinsi dan Kabupaten kurang memperhatikan aspek perbaikan terhadap penataan administrasi pemerintahan desa, sebagai dasar untuk merumuskan dan menetapkan operasianalisasi kebijakan pembangunan pada tingkat desa. (Wahyudin,2015:15) menyebut perencanaan pembangunan desan mencakup penyusunan perencanaan pembangunan desa, baik itu penyusunan Rencana Pembangunan Jangka Menengah Desa (RPJMDes), maupun Rencana 
Kerja Pemerintah Desa (RKPDes), pentingnya aspek perencanaan pembangunan belum dirumuskan oleh pemerintah desa berdasarkan data dan informasi yang akurat sesuai kondisi ril yang ada di desa. Ketidaktertiban administrasi pemerintahan desa, juga berdampak pada efektivitas program-program pemerintah yang ditujukan ke desa, tidak tepat sasarannya program pemerintah yang selalu menjadi masalah selama ini, salah satunya disebabkan karena data dan informasi yang tidak akurat sesuai kondisi realitas yang ada di desa.

\subsection{Identifikasi dan Perumusan Masalah}

Masalah konkrit yang dihadapi Pemerintah Desa Kualu Nenas dalam tata kelola penyelenggaraan administrasi pemerintahan desa ialah belum adanya sistem administrasi desa yang lengkap sesuai dengan pedoman yang telah di standarkan oleh Kementerian Dalam Negeri. Masalah tersebut dikarenakan masih kurangnya pemahaman aparatur penyelenggara pemerintahan desa di desa Kualu Nenas mengenai sistem administrasi desa yang baik dan benar. Adapun yang menjadi perrumusan masalah dalam kegiatan pengabdian masyarakat ialah :

a. Minimnya pemahaman aparatur desa Kualu Nenas terkait administrasi pemerintahan desa yang baik dan benar sebagai data dan informasi dalam penyelenggaraan pemerintahan dan pembangunan.

b. Belum adanya buku pedoman administrasi pemerintahan desa di Desa Kualu Nenas yang sesuai dengan Peraturan Menteri Dalam Negeri Nomor 47 tahun 2016 tentang administrasi pemerintahan desa.

c. Belum adanya teknologi informasi pembangunan desa di Desa Kualu Nenas yang berbasis online, yang dapat diakses oleh masyarakat.

\subsection{Tujuan Kegiatan Pengabdian}

Adapun tujuan dari pengabadian masyarakat yang akan dilaksanakan ialah:

a. Untuk memberikan pemahaman kepada para aparatur desa terkait administrasi pemerintahan desa yang baik dan benar sebagai basis data dan informasi terdepan dalam penyelenggaraan pemerintahan dan pembangunan desa di Desa Kualu Nenas

b. Terciptanya buku administrasi pemerintahan desa di Desa Kualu Nenas yang tertib, sebagai basis data informasi desa dalam pemberian layanan kepada masyarakat.

c. Terciptanya teknologi informasi pembangunan desa di Desa Kualu Nenas berbasis online.

\subsection{Kerangka Pemecahan Masalah}

\section{METODE}

Keberhasilan penyelenggaraan pemerintahan desa, terutama dalam pelaksanaan urusan pemerintahan dan pelaksanaan pembangunan, akan tergantung kepada perencanaan. Penyusunan perencanaan akan bersumber kepada data dan informasi. Kebijakan Pemerintah yang sangat ideal untuk mewujudkan otonomi desa yang mandiri selalu tidak berjalan sesuai dengan tujuan kebijakan itu sendiri. Tahapan Implementasi Kebijakan adalah siklus kebijakan publik yang selalui menuai berbagai macam persoalan yang disebabkan tidak akuratnya data dan informasi pada tingkatan pemerintahan yang paling terendah yaitu pemerintahan desa.

Desa Kualu Nenas Kecamatan Tambang Kabupaten Kampar ialah salah satu desa yang masih memiliki data dan informasi yang tidak akurat, karena disebabkan belum optimalnya pengadministrasian Desa seperti yang tertuang dalam Peraturan Menteri Dalam Negeri Nomor 47 Tahun 2016 Tentang Administrasi Pemerintahan Desa.

Sebagai kerangkan pemecahan masalah yang dipaparkan tersebut, pada penyelenggaraan Tata Kelola Pemerintahan Desa di Desa Kualu Nenas, Tim Pengbdi dalam kegiatan ini dalam rangka memecahkan masalah tersebut ialah dengan melakukan Pelatihan Administrasi Tata Usaha Kantor Desa, dengan cara;

1. Memberikan paparan materi tentang administrasi pemerintahan Desa berdasarkan Peraturan Menteri Dalam Negeri Nomor 47 Tahun 2016 Tentang Administrasi Pemerintahan Desa.

2. Mendemonstrasikan pengisian Buku Administrasi Desa sesuai dengan Peraturan Menteri Dalam Negeri Nomor 47 Tahun 2016 Tentang Administrasi Pemerintahan Desa

3. Memaparkan rancangan administrasi pemerintahan desa yang berbasis online 


\subsection{Kelompok Sasaran Antara Yang Strategis}

- Adapun yang menjadi kelompok sasaran dalam kegiatan pengabdian ini ialah Kepala Desa, Sekretaris Desa dan Perangkat Desa Lainnya, BPD, Lembaga Kemasyarakatan Desa (LKD), dan Kelembagaan-Kelembagaan Desa yang ada di Desa Kualu Nenas.

\subsection{Metode Pelaksanaan}

Metode Pelaksanaan kegiatan pengabdian dilakukan dengan cara sebagai berikut :

a. Penyampaian materi tentang tata cara pengadministrasian Tata Usaha Kantor Desa berdasarkan Peraturan Menteri Dalam Negeri Nomor 47 Tahun 2016 Tentang Administrasi

b. Pemerintahan Desa Desa yang berisi : Administrasi Umum adminisitrasi umum, administrasi penduduk, administrasi keuangan, administrasi pembangunan, administrasi Badan Permusyawaratan Desa (BPD) dan administrasi lainnya.

c. Memnfasilitasi pembuatan buku administrasi desa secara lengkap

d. Memfasilitasi pembuatan administrasi pemerintahan desa yang berbasis online

\section{HASIL DAN PEMBAHASAN}

Kegiatan pengabdian kepada masyarakat tentang administrasi pemerintahan desa, di desa Kualu Nenas Sesuai dengan tujuan awal kegiatan pengabdian ini ialah Untuk memberikan pemahaman kepada para aparatur desa/staf desa terkait administrasi pemerintahan desa yang baik dan benar sebagai basis data dan informasi terdepan dalam penyelenggaraan pemerintahan desa di Desa Kualu Nenas. Adapun tahapan kegiatan pengabdian yang dilakukan dirincikan pada tabel dibawah ini.

Tabel 4 Hasil Kegiatan Pengabdian

\begin{tabular}{|c|c|c|c|}
\hline No & $\begin{array}{c}\text { Kegiatan Pengabdian Yang } \\
\text { Dilaksanakan }\end{array}$ & Hasil & Keterangan \\
\hline 1. & $\begin{array}{lrr}\text { Pembuatan } & \text { Modul } & \text { dan } \\
\text { Penyerahan } & \text { Modul Praktek } \\
\text { Administrasi } & \text { Pemerintahan } \\
\text { Desa } & & \end{array}$ & $\begin{array}{l}\text { Modul sebagai bahan dalam } \\
\text { melakukan kegiatan pelatihan } \\
\text { administrasi pemerintahan desa di } \\
\text { Desa Kualu Nenas }\end{array}$ & $\begin{array}{l}\text { Modul Praktek } \\
\text { Administrasi } \\
\text { Pemerintahan } \\
\text { Desa di serahkan } \\
\text { kepada aparat desa } \\
\text { Kualu Nenas }\end{array}$ \\
\hline 2. & $\begin{array}{l}\text { Penyampaian Materi Tentang } \\
\text { Admnistrasi Pemerintahan } \\
\text { Desa yang baik dan benar. }\end{array}$ & $\begin{array}{l}\text { Aparat Desa Kualu Nenas dapat } \\
\text { memahami dan mengerti tentang } \\
\text { administrasi pemerintahan desa } \\
\text { sebagaimana yang diatur dalam } \\
\text { Permendagri No. } 47 \text { Tahun } 2016 \\
\text { Tentang Administrasi Pemerintahan } \\
\text { Desa }\end{array}$ & $\begin{array}{l}\text { Materi yang } \\
\text { disampaikan } \\
\text { tentang } \\
\text { administrasi } \\
\text { umum, } \\
\text { administrasi } \\
\text { penduduk, } \\
\text { administrasi } \\
\text { keuangan, } \\
\text { administrasi } \\
\text { pembangunan, } \\
\text { administrasi BPD } \\
\text { dan kelembagaan } \\
\text { desa lainnya, } \\
\text { pengisian profil } \\
\text { desa. }\end{array}$ \\
\hline 3 & $\begin{array}{l}\text { Pembuatan Buku Administrasi } \\
\text { Pemerintahan Desa }\end{array}$ & $\begin{array}{l}\text { Aparatur Desa Kualu Nenas } \\
\text { melakukan penyiapan data }\end{array}$ & $\begin{array}{l}\text { Melakukan } \\
\text { pencatatan }\end{array}$ \\
\hline
\end{tabular}




\begin{tabular}{lll}
\hline & & $\begin{array}{l}\text { kedalam buku } \\
\text { administrasi }\end{array}$ \\
\hline 4. & $\begin{array}{l}\text { Presentasi Aplikasi } \\
\text { Administrasi Pemerintahan } \\
\text { Desa Berbasis Online }\end{array}$ & Aplikasi Masih berbentuk \\
Rancangan & $\begin{array}{l}\text { Belum dapat } \\
\text { digunakan }\end{array}$ \\
\hline
\end{tabular}

Sumber : Data Olahan Tim Pengabdi, 2017

Dalam kegiatan penyampaian materi mengenai administrasi pemerintahan desa yang telah dibuat tim pengabdi dalam sebuah modul, diikuti oleh seluruh aparatur/staf desa Kualu Nenas, pada saat penyempaian materi para peserta ternyata baru mengetahui ada panduan pengelolaan tata kelola administrasi pemerintahan desa yang telah diatur dalam Peraturan Menteri Dalam Negeri Nomor 47 tahun 2016 tentang Administrasi Pemerintahan Desa. Para peserta mengakui bahwa selama ini, mereka tidak membuat administrasi sesuai dengan aturan. Setelah dilakukan kegiatan pelatihan kepada aparatur desa di Desa Kualu Nenas didapatkan hasil bahwa, aparatur Desa Kualu Nenas telah memahami tata cara pengisian buku administrasi pemerintahan desa sesuai dengan standar yang telah ditetapkan, dan semuat staf di Kantor Desa Kualu Nenas dapat mempraktekkannya dalam penyelenggaraan pemerintahan di Desa Kualu Nenas.
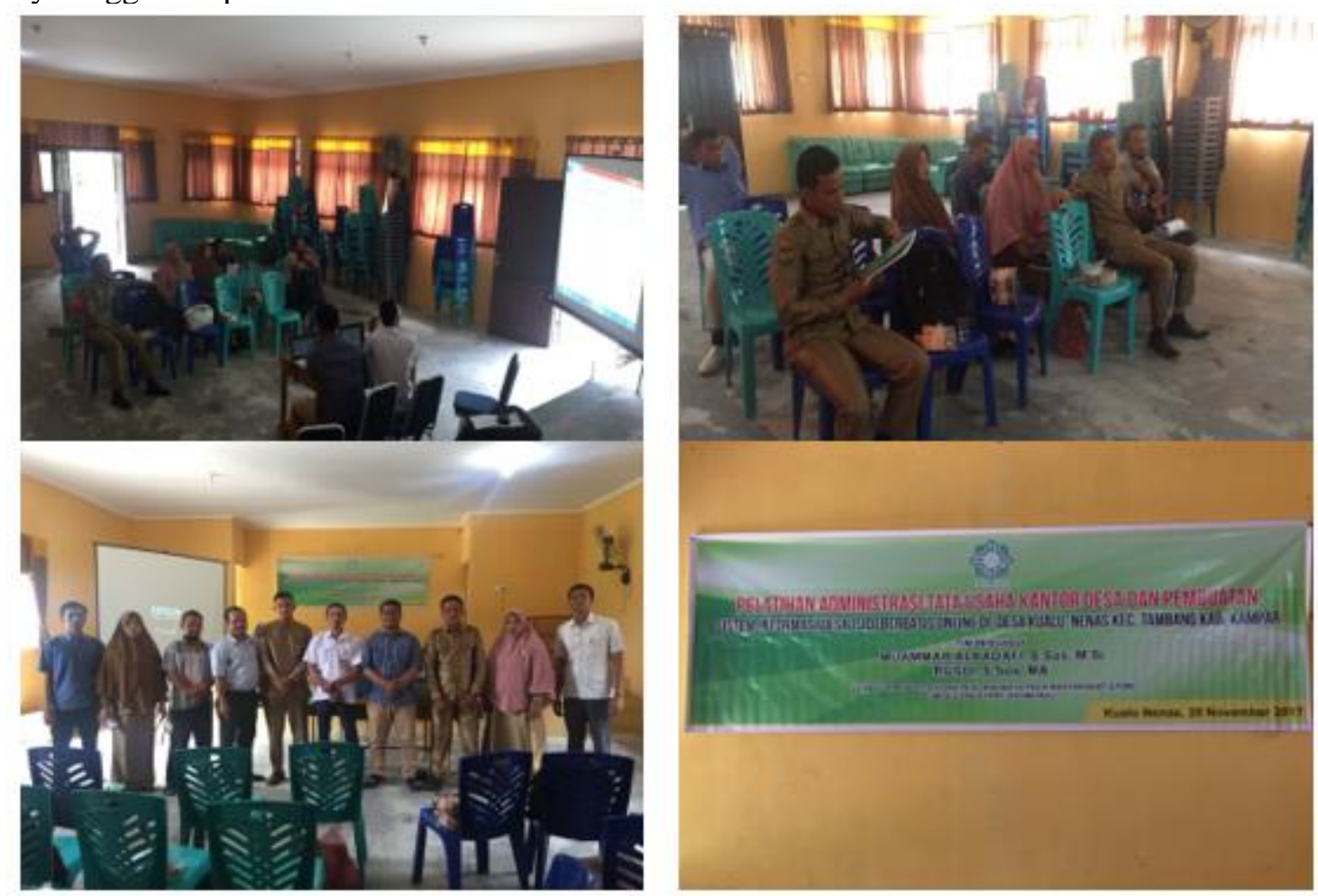

Gambar 3 Paparan Materi Administrasi Pemerintahan Desa Oleh Tim Pengabdi

Berikut model administrasi pemerintahan desa, yang wajib ditata secara baik dan benar pada setiap penyelenggara pemerintahan desa.

1. Administrasi Umum Desa
a. Model A 1 Buku Peraturan Di Desa
b. Model A 2 Buku Data Keputusan Kepala Desa
c. Model A 3 Buku Inventaris dan Kekayaan Desa
d. Model A 4 Buku Aparat Pemerintah Desa
e. Model A 5 Buku Tanah Kas Desa
f. Model A 6 Buku Tanah di Desa
g. Model A 7 Buku Agenda
h. Model A 8 Buku Ekspedisi, dan
i. Model A 9 Buku Lembaran Desa dan Buku Berita Desa 
2. Administrasi Penduduk
a. Model B 1
Buku Induk Penduduk Desa
b. Model B 2
Buku Mutasi Penduduk Desa
c. Model B 3
Buku Rekapitulasi Jumlah Penduduk
d. Model B 4
Buku Penduduk Sementara
e. Model B 5
Buku Kartu Tanda Penduduk dan Buku Kartu Keluarga

3. Administrasi Keuangan Desa
a. Model C 1.
Buku APB Desa
b. Model C 2
Buku Rencana Anggaran Biaya
c. Model C 3
Buku Kas Pembantu Keigatan
d. $\quad$ Model C 4
Buku Kas Umum
e. Model C 5
Buku Kas Pembantu
f. Model C 6
Buku Bank Desa

4. Administrasi Pembangunan Desa
a. Model D 1 Buku Rencana Kerja Pembangunan Desa
b. Model D 2 Buku Kegiatan Pembangunan
c. Model D 3 Buku Inventarisasi Hasil-Hasil Pembangunan, dan
d. Model D 4 Buku Kader Pendampingan dan Pemberdayaan Masyarakat

5. Administrasi Lainnya
a. Model F 1 Buku Profil Desa
b. Model F2 Buku BPD
c. Model F3 Buku Kelembagaan Desa
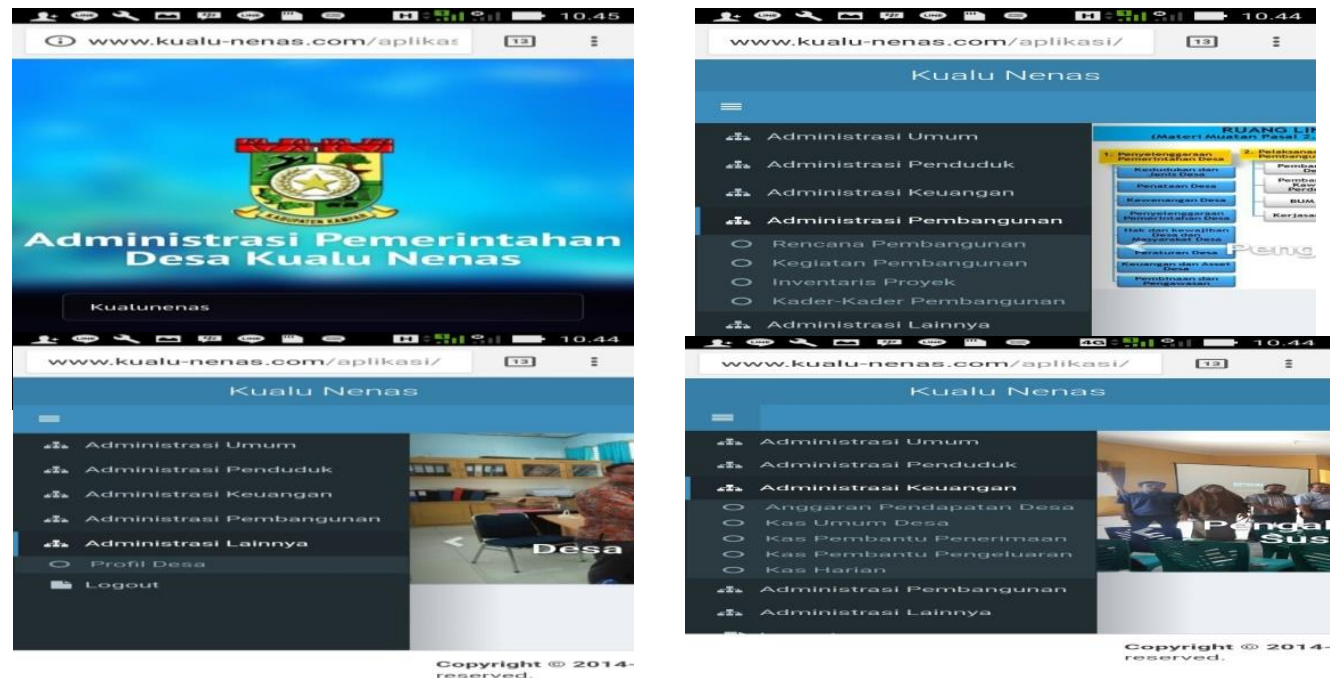

Gambar 2 Rancangan Administrasi Pemerintahan Desa Berbasis Aplikasi Online

\section{KESIMPULAN}

Kegiatan pengabdian kepada masyarakat di desa binaan UIN Suska Riau didapatkan hasil. Pertama, Aparatur Desa Kualu Nenas telah memahami penataan Administrasi Pemerintahan Desa yang baik dan benar sesuai dengan pedomanan yang tertuang dalam Peraturan Menteri Dalam Negeri Nomor 47 tahun 2016. Kedua, Aparatur Desa Kualu Nenas telah mengetahui tata cara pengisian buku administrasi pemerintahan desa, dan dapat mempraktekkannya dalam penyelenggaraan pemerintahan. Ketiga, telah terciptanya data dan informasi yang akurat dalam penyelenggaraan pemerintahan dan pembangunan di Desa Kualu Nenas. 4, memudahkan aparatur Desa Kualu Nenas dalam memberikan pelayanan publik yang lebih berkualitas. 5, dengan adanya rancangan sistem informasi administrasi pemerintahan desa Kualu Nenas apabila dimanfaatkan, dapat memudahkan 
masyarakat mengakses data informasi yang cepat, efisien dan efektiv, dan sistem informasi yang berbasis aplikasi tersebut dapat memudahkan aparatur Desa Kualu Nenas untuk mengupdate pengisian buku administrasi umum, administrasi penduduk, administrasi keuangan, administrasi pembangunan, administrasi BPD, administrasi kelembagaan desa lainnya dan profil desa yang lebih akurat. Kemudian sistem informasi administrasi pemerintahan desa Kualu Nenas apabila dimanfaatkan juga dapat memudahkan akses Pemerintah Kecamatan, Pemerintah Kabupaten, Pemerintah Provinsi dan Pemerintah Pusat untuk mengetahui kegiatan pembangunan di Desa Kualu Nenas dan perkembangannya.

\section{SARAN}

Dari hasil pelaksanaan kegiatan pengabdian, tim pengabdi memberikan saran sebagai berikut :

a. Kepada aparatur Desa Kualu Nenas, untuk dapat secara konsisten dan berkelanjutan melakukan pendataan untuk mengisi data-data informasi mengenai penyelenggaraan pemerintahan Desa, pelaksanaan pembangunan, pembinaan kemasyarakatan dan pemberdayaan masyarakat sesuai dengan buku administrasi yang telah dibuat.

b. Kepada aparatur desa untuk segera menghadirkan jaringan internet di Desa Kualu Nenas dan pengadaan komputer untuk mendukung pengelolaan administrasi yang lengkap di Desa Kualu Nenas.

c. Rancangan Sistem Informasi Administrasi Pemerintahan Desa Kualu Nenas yang telah dibuat untuk dapat diselesaikan dan disempurnakan, agar dapat dimanfaatkan untuk memudahkan penyebaran informasi data-data yang telah tercatat dalam setiap buku administrasi.

\section{UCAPAN TERIMA KASIH}

Penulis mengucapkan terima kasih kepada Lembaga Penelitian dan Pengabdian Kepada Masyarakat (LPPM) Universitas Islam Negeri Sultan Syarif Kasim Riau yang telah memberi dukungan anggaran terhadap pengabdian ini.

\section{DAFTAR PUSTAKA}

[1] Hanibal Hamidi, Nugroho, Fujitriartanto, Armen Sa'id, Harioso, Andik Hardiyanto, Bambang Waluyanto, Indra Sakti Gunawan Lubis, Dani Setiawan, Hadi Prayitno, Ana Fitrotul Mu'arofah, 2015. Indeks Desa Membangun, Jakarta, Kementerian Desa Pembangunan Daerah Tertinggal, dan Transmigrasi Republik Indonesia, Jakarta.

[2] Kurniawan Borni, 2015, Desa Mandiri, Desa Membangun, Kementerian Desa Pembangunan Daerah Tertinggal dan Transmigrasi Republik Indonesia, Jakarta.

[3] Kessa Wahyudin, 2015, Perencanaan Pembangunan Desa, Kementerian Desa Pembangunan Daerah Tertinggal dan Transmigrasi Republik Indonesia, Jakarta.

[4] Silahuddin, 2015, Kewenangan Desan dan Regulasi Desa, Kementerian Desa Pembangunan Daerah Tertinggal dan Transmigrasi Republik Indonesia, Jakarta.

[5] Undang - Undang Republik Indonesia Nomor 6 Tahun 2014 Tentang Desa. 15 Januari 2014. Lembaran Negara Republik Indonesia Tahun 2014 Nomor 7, Jakarta.

[6] Peraturan Menteri Desa, Pembangunan Daerah Tertinggal, dan Transmigrasi Republik Indonesi Nomor 2 Tahun 2016 Tentang Indeks Desa Membangun.18 Februari 2016. Berita Negara Republik Indonesia Tahun 2016 Nomor 300.

[7] Peraturan Menteri Dalam Negeri Negara Republik Indonesia, Nomor 47 Tahun 2016, Tentang Administrasi Pemerintahan Desa. 11 Juli 2016. Berita Negara Republik Indonesia Tahun 2016 Nomor 1100.

[8] Peraturan Menteri Dalam Negeri Negara Republik Indonesia Nomor 81 Tahun 2015 Tentang Evaluasi Perkembangan Desa dan Kelurahan. 30 Desember 2015 Berita Negara Republik Indonesia Tahun 2015 Nomor 2037. 